\title{
Legal Monitoring in the Eurasian Economic Space
}

\author{
Vlada Lukyanova \\ Department of Legal Analysis and Sociology of Law of the Institute of Legislation and Comparative Law Under the Government of the Russian \\ Federation (ILCL), Moscow, Russian Federation
}

Email address:

vlada.lukianova@rambler.ru

\section{To cite this article:}

Vlada Lukyanova. Legal Monitoring in the Eurasian Economic Space. International Journal of Law and Society. Vol. 4, No. 1, 2021 , pp. 10-22. doi: $10.11648 /$ j.ijls.20210401.12

Received: December 28, 2020; Accepted: January 8, 2021; Published: January 28, 2021

\begin{abstract}
Currently, legislation is rapidly developing in many countries of the world. The governing bodies of interstate integration associations, such as the EU or the Eurasian Economic Union, are no less intensive in their normative activities. The high intensity of these processes is due to the scale of the challenges and threats faced by states and interstate integration associations. Unfortunately, poor implementation of laws remains a weak point. To assess the effectiveness of laws, states and interstate integration associations are developing new legal techniques. Legal monitoring is a cutting-edge legal technique that allows assessment of regulatory effectiveness. It is an integrated structural and analytical mechanism for analyzing and assessing a regulatory act across all stages of development and adoption. The paper discusses the problems related to implementing legal monitoring in the Eurasian Economic Union (EEU), a body that encompasses Armenia, Belarus, Kazakhstan, Kyrgyzstan and Russia. The purposes of this paper are: (1) to study the theoretical, legal and organizational backgrounds of legal monitoring as a tool for improving legal effectiveness in the EEU and its member states at the supranational and national levels; and (2) the development of proposals for upgrading regulation of public relations emerging as a result of legal monitoring procedures carried out in the EEU. To fulfil these purposes, theoretical, methodological and legal frameworks of legal monitoring by governmental authorities in the EEU member states and by the Eurasian Economic Commission, the EEU's permanent executive body, were studied. Special priority was accorded to the monitoring activities that the Commission carried out to identify the measures the EEU member states took to mitigate the effects of the coronavirus disease (COVID-19) outbreak. Another significant line of research was identifying and studying organizational models that frame the monitoring of law-making in the EEU. The analysis allowed the author to prepare proposals to improve the legal framework of legal monitoring by the EEU's permanent executive bodies and the integrated legal monitoring system in the Eurasian economic space.
\end{abstract}

Keywords: Regional Economic Integration, Eurasian Economic Union, Law Terminology, Legal Monitoring, Legislation Effectiveness

\section{Introduction}

Development of international relations is characterized by a transition from the unipolar to the multipolar, demonstrating the accelerated transformation of political configurations that have formed on the global stage over recent years. One example has been the emergence in the Eurasian economic space of a rapidly evolving interstate association called the Eurasian Economic Union (EEU), the purpose of which was ensuring 'freedom of goods, services, capital and labor mobility and performance of the coordinated, integrated policy across various economic fields', as stipulated in the
Treaty of the Eurasian Economic Union dated May 29, 2014 (the EEU Treaty) and the Union's international legal acts [17, Article 1].

Just like the establishment of any other interstate integrated association, the formation of the EEU saw the emergence of a special legal framework made up of the following components:

International legal documents of the Union, including the EEU Treaty that formalized the integrated association, international acts, and other acts, including acts of the EEU governing bodies, which constitute the Union law; national legislation of the EEU member states; and other social regulators formed within religious, ethnic, local, and 
professional communities [5].

The efficiency of the EEU formation and operation relies on: (1) how relevant the tools of international integration (including the Union law), are to the specifics of the Union and its external environment; and (2) how aligned and harmonized the member states' national legislations are. Therefore, two factors harm the performance of the processes: siloed changes to the member states' national legislation; and the rapid increase of legal acts forming the EEU's legal framework.

Those differences in national approaches will be explored in this paper [7]. Law-making is especially active in member states because securing a nation's social and economic growth requires exploiting various regulators, one of which is the law, the legal framework that spans opportunities, social life, economic and social activities. Transition 'from the establishment of developed socialism to capitalism' and refocusing on market relations required a systemic transformation of national legislation. This metamorphosis in some industries turned out to be so significant that they were virtually re-established.

At the supranational level - the level of the EEU - the scope of legal regulation has also seen fast growth. Under Article 6 of the EEU Treaty, the Union's legal framework comprises two types of international law sources: international treaties, which include the EEU Treaty, international treaties that are part of Union law and international treaties between the Union and third parties; and acts adopted by the EEU authorities, primarily the Supreme Eurasian Economic Council and the Eurasian Economic Commission. Union law also includes some other types of international treaties, some of which can be treated as types of agreements stipulated in Article 6. Under Article 99 , international treaties of the member states concluded as part of the contractual and legal framework of the Customs Union and the Eurasian Economic Space and having legal force as of the effective date of the EEU Treaty, shall be part of the Union law as international treaties and applied to the extent they are not inconsistent with the EEU Treaty. Appendix 31 that contains the Protocol on Operation of the EEU as part of the Multilateral Trade System, the Agreement on Operation of the Customs Union as part of the Multilateral Trade System dated May 19, 2011, shall be applied to the respective treaties under Union law [6]. The analysis shows the rapid growth of the number of international treaties concluded within the Union or to which the Union is a party and the number of legally binding acts adopted by the Union's authorities (see Figure 1). This may involve inconsistency and gaps in the Union law, which will inevitably result in a lower effectiveness and efficiency thereof.

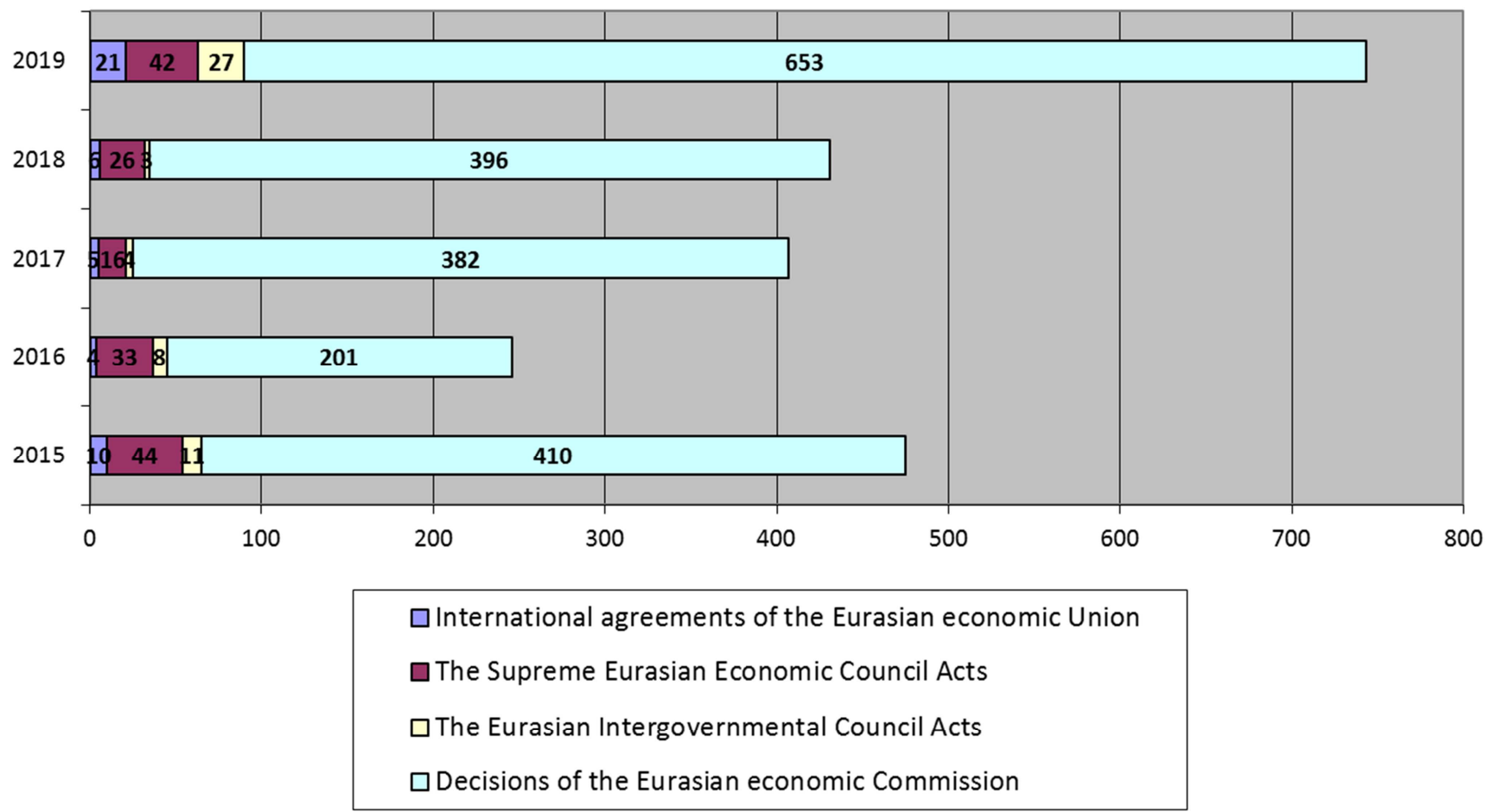

Source: Data from the official websites of the EEU and the Eurasian Economic Commission.

Figure 1. Law-making in the EEU.

In such a situation, the problem of 'integrating the three kinds of legal regulation - an international treaty, a legal act adopted by international law and a legal act adopted by national authorities' becomes even more acute [9]
(Neshatayeva 2015). To address it, new legal technologies are being developed - both at the supranational (the EEU) and the national levels (member states) - to analyze and assess the effects of legal acts. Such technologies include legal 
monitoring technology; in the Eurasian economic space, however, this has many different approaches.

This paper consists of three parts. The first is devoted to the theoretical and legal basis of legal monitoring carried out at the supranational and national levels. The second concerns specifics of monitoring activity in the member states of the EEU, with special attention to identifying and studying organizational models of legal monitoring. In its third part, the paper investigates how legal monitoring is carried out by the EEU's permanent executive body, the Eurasian Economic Commission, and considers options for organizing such monitoring activities, and discusses informational and software support of interaction between legal monitoring subjects. The paper provides suggestions and recommendations on optimizing the mechanism of legal monitoring of international and interstate acts and other legally binding acts that constitute the law of the EEU.

\section{Literature Review}

\subsection{Legal Monitoring in the Law of the EEU}

Legal monitoring is a relatively new phenomenon in the theory and practice of law-making and law administration in the Eurasian economic space. Usually, by legal monitoring, the researchers mean a special legal technology that has three objectives. The first is identifying shortcomings of law-making and law administration; gaps, collisions and conflicts between legal acts of the same legal force and between acts of different levels (e.g. supranational and national, federal and regional). The second is ensuring a scientifically validated approach to choosing lines of legislative development. The third is to ensure the internal consistency of the legal framework.

Legal monitoring ensures systematic observation, assessment and analysis of the law dynamics [11], and is one of the cornerstone instruments to enhance the effectiveness and quality of legal acts and their implementation [3]. This problem of effectiveness is a concern for regulatory systems of both member states and the entire EEU. Monitoring research in the EEC is governed both by national legislation and elements of international and supranational laws. However, contemporary legal science has only recently turned its focus to studying the problems of legal monitoring and despite - or perhaps because of - its considerable value in improving law-making and law implementation, the law experts of member states have not developed any integrated approach to defining it. For instance, Tikhomirov defines this legal technique as:

an agile organizational and legal instrument, which carries the informational and evaluative nature, spans all the stages of operation, business activities, etc. and demonstrates its effect across all the stages of creation and force of law [14].

According to Tolmachyova, 'law monitoring' implies monitoring of legislation and law implementation, defined as: a method for state regulation of the projected, current and future status and practice of implementing law and legal acts thereunder. Basically, the method is systemic and regular collection and analysis of information as to the status of observed law - aimed at employing state regulation and enforcement practices to prevent and eliminate inappropriate and unfavorable repercussions of implementation of such law [16].

Ivanova [4] and Fadeyeva [2] regard legal monitoring as an analytical and evaluative, methodologically grounded, integrated and systematic activity of authorized bodies, which includes observation, analysis, quality assessment of legal regulations and implementation, analyzing whether its purposes and objectives are fulfilled. It also includes forecasting of paths of development of law-making and law implementation. Kazakh scholars see legal monitoring as a special mechanism to enhance effectiveness of legal regulation of public relations, which is vested with functions to evaluate legislation and implementation thereof and to forecast development of legal phenomena [15].

Belarussian scholars consider this technique: an activity aimed at systematic analysis and quality assessment of legislation, law implementation, effectiveness of legal regulation of public relations - carried out by law-making authorities (officials) and other governmental institutions within their respective competences. Following the results of this activity, proposals on improving legislation and law implementation and drafts of legal acts are developed and measures on proper implementation thereof are taken [12].

In the context of legitimate approaches to defining the term 'legal monitoring', the law of the EEU provides no definition although it is concerned with developing a legal monitoring system. Some experts [9, 10] suggest referring to the Resolution of the Appeals Chamber of the Court of the EEU dated October 7, 2014, on the claim from Vichunai-Rus LLC to the Eurasian Economic Commission [13]. This resolution defines legal monitoring in the EEU as 'a legal authority's analysis of legal relations to verify compliance of obligated parties with legal regulations.' The result of legal monitoring is establishing compliance or non-compliance of obligated parties with legal regulations. In the case of compliance, the law's implementation process shall be considered completed, while in non-compliance, according to the Court, a fact of non-compliance shall be followed by the authorized legal authority making an order instructing the obliged party to comply with legal regulations.

Such a definition of monitoring may not be seen as well-reasoned as it does not reflect one of the most critical attributes of monitoring activities - regularity. Some English dictionaries confirm that monitoring activity must be regular. The Collins English Dictionary stipulates that '[i]f you monitor something, you regularly check its development or progress and sometimes comment on it'. ${ }^{1}$ The Cambridge

\footnotetext{
1 See Collinsdictionary,

https://www.collinsdictionary.com/dictionary/english/monitor Accessed on August 6, 2020.
} 
Dictionary defines the verb 'to monitor' as 'to watch and check a situation carefully for a period of time to discover something about it'. ${ }^{2}$

The Russian dictionary's definition of 'monitoring' translates as 'a system of regular observations, evaluations and forecasts as to the status of a natural, social, or another object'. ${ }^{3}$ And it is those regular observations that allow monitoring how the object changes in real-time and suggest managerial solutions that could embrace such changes and secure the expected result.

This way of defining and perceiving monitoring activities is also typical of the justice system. ${ }^{4}$ However, the Resolution regards monitoring not as a regular activity, but as a one-time action performed by the Commission on suspicion of a violation of the rights and legitimate interests of the general public.

Given this, it was predictable that in 2016, the Court of the EEU proposed a different definition of 'legal monitoring'. According to Clause 8.7 of the reasoning of the Resolution of the Appeals Chamber dated March 3, 2016, on a claim of an omission by the Commission as inappropriate and violating the EEU law and breaching the rights and legitimate interests of citizens, ${ }^{5}$ monitoring was defined as:

'a Union's authorized body's activity as to collect, generalize and evaluate information regarding adherence of the member states to the international treaties which are part of the Union law and resolutions of the Union's bodies, to ensure uniform and effective legal regulation in the Union'.

Monitoring is defined as 'a continuous process of observation which helps identify shortcomings that inhibit uniform and effective legal regulation, putting forward suggestions on enhancing the Union law and harmonizing legislation of the Union's member states. As the document goes, 'according to the essence of the EEU Treaty, Statute of the Commission and the Treaty of the Eurasian Economic Commission dated November 18, 2011, ${ }^{6}$ the Commission shall carry out monitoring regularly, holistically, without being initiated by an individual request. ${ }^{7}$ In this regard, 'evaluating fulfilment by the member states of the international treaties and resolutions of the Union's bodies and

2See Cambridge Dictionary,

https://dictionary.cambridge.org/dictionary/english/monitor Accessed on August 6, 2020 .

3 Large Dictionary of Foreign Words, https://gufo.me/dict/foreign_words.

4 See Federal Law No. 96-FZ dated May 4, 1999, 'On protection of natural air' // Collected Acts of the Russian Federation. 1999. Issue 18. Article 2222 of Federal Law No. 44-FZ dated April 5, 2013 'On the contractual system in procurement of goods, works and services for public and municipal use' // Collected Acts of the Russian Federation. 2013. Issue 14. Article 1652, Decree of the President of the Russian Federation No. 657 dated May 20, 2011 'On law implementation monitoring in the Russian Federation' // Collected Acts of the Russian Federation. 2011. Issue 21. Article 2930.

5 See Official website of the Court of the Eurasian Economic Union, http://courteurasian.org/.

6 The case went on for several years and the Treaty had expired (on January 1, 2015 ) by the time the final resolution was issued. However, the principles remain in effect.

7 Clause 8.6 of Resolution of the Appeals Chamber of the Court of the Eurasian Economic Union dated March 3, 2016. preparation of suggestions on improving the Union law' were declared the key purposes of monitoring.

This approach, compared to the approach the Court proposed in 2014, better reflects the specifics of legal monitoring as a legal technique that allows evaluating the effectiveness of legal regulation. Under this revised approach, legal monitoring appears as an integrated structural and analytical mechanism that is 'called to ensure systematic observation, evaluation and analysis of the justice system dynamics' [11] and thus help maintain the quality of the adopted legal acts and their implementation. Similarly, the resolution on Case No. CE-1-2/4-18-KC dated 11 October 2018 recognized an omission by the Commission as not consistent with the EEU Treaty and Union law and violating the rights and legitimate interests of a legal person.

In the EEC, legal monitoring studies are regulated not only by the EEU Treaty and legally binding acts that are part of the Union law, but also legal and other regulatory acts adopted by member states. However, the member states employ different approaches to defining legal monitoring and its role in defragmenting the EEU's legal framework.

\subsection{Legal Monitoring Research in Member States}

Most EEU member states provide for legal monitoring in their legislation. Examples include:

Law of the Republic of Belarus dated July 17, 2018, No. 130-3 'On legal acts' (RB Law No. 130-3).

Enactment of the Council of Ministers of the Republic of Belarus dated January 30, 2019, No. 65 'On the Procedure for legal monitoring'.

Law of the Republic of Kazakhstan dated April 6, 2016, No. 480-V ZRK 'On legal acts' (RK Law No. 480-V ZRK).

Enactment of the Government of the Republic of Kazakhstan dated August 29, 2016, No. 486 'On approval of the Procedure for legal monitoring'.

Decree of the President of the Russian Federation dated May 20, 2011, No. 657 'On law implementation monitoring in the Russian Federation'.

Enactment of the Government of the Russian Federation dated August 19, 2011, No. 694 'On approval of the methodology for law implementation monitoring in the Russian Federation.

Article 33-1 of Law of the Kyrgyz Republic dated July 20, 2009, No. 241 'On legal acts of the Kyrgyz Republic' considers not just monitoring itself but also evaluation of legal acts to determine their effectiveness and efficiency. This law, however, does not define 'evaluation of legal acts', but orders the Government to establish a procedure for evaluation and monitoring. However, the Enactment of the Government of the Kyrgyz Republic dated March 23, 2015, No. 139 'On approval of the Procedure for Monitoring and Evaluation of Effectiveness of Legal Acts of the Kyrgyz Republic' reduces the matter to monitoring, defining it as systematic analysis and evaluation of the effectiveness of legal acts adopted by the supreme executive body.

Compared to other EEU member states, the Russian Federation regulates the procedure not of legal monitoring 
itself, but of law implementation monitoring, whose core declared purpose is the enhancement of the legislative framework of the Russian Federation. ${ }^{8}$

In Armenia, there is no single procedure for legal monitoring of all the parties involved in the law-making process. This does not mean that Armenia does not carry out any monitoring research in legislation; quite the contrary, Armenian researchers have accumulated considerable knowledge and ability to carry out such monitoring activities [1].

Appendix 1 presents a comparative analysis of the regulation, organization and implementation of legal monitoring in the EEU countries. The results of this analysis and analysis of the EEU Treaty clauses and other legal acts of the Union that govern legal monitoring, suggest the following. The ultimate goal of legal monitoring studies is the enhancement of a country's legal framework or interstate association. This is achieved through: systematic analysis and evaluation of law-making and implementation quality; identification of obsolete, corrupt and ineffective elements of law; evaluation of whether law implementation practices are adequate to the expected result of legal regulation; and development of proposals to enhance legal regulation.

In all EEU member states and in the Union itself, the object of monitoring is effective legal acts of different levels and legal force - from national constitutions to the legal acts of local governments. National legislations do not provide for the monitoring by member states of international treaties within the Union and legally binding resolutions of the Union's bodies including the Commission. This monitoring of compliance constitutes legal monitoring in the EEU.

At both the supranational and EEU level, there are provisions stipulating two types of legal monitoring studies: regular monitoring, which is usually based on annual plans and one-time, situation-based monitoring. There may be a different categorization of monitoring studies, under which there are mandatory and voluntary, initiative-based studies. According to the Procedure for Law Implementation Monitoring in the Russian Federation, approved by Decree of the President of the Russian Federation dated May 20, 2011, No. 657, law implementation monitoring should be carried out consistently with the monitoring plan, but apart from such activities, federal executive bodies, executive bodies of the constituents of the Russian Federation and local governments can carry out monitoring activities they voluntarily initiate.

As with any other social activity, legal monitoring relies on a set of principles that include legitimacy, objectivity, bindingness and informational transparency. This principle has two core aspects. First, monitoring studies may only carry informational value given comprehensive and credible information as to the legislation's current status and statistical and other data. This information must be kept up-to-date and systematized depending on the objectives. Second, legal

8 See Decree of the President of the Russian Federation No. 657 dated May 20, 2011 'On law implementation monitoring in the Russian Federation'. Collected Acts of the Russian Federation. 2011. Issue 21. Article 2930. monitoring results must be published according to the manner defined by the legislation of an EEU member state or the Union's legal act.

EEU member states have a variety of institutional models of law-making monitoring with a system of executive bodies, their structural subdivisions, officials and other concerned parties involved in legal monitoring activities and provision of a procedure.

The analysis of the legal acts and member states legislation of the EEU that govern the procedure for legal monitoring suggests two institutional models: the distributed model and the centralized model. The distributed model of legal monitoring is characterized by a multiplicity and equivalence of legal monitoring entities. Under this model, the principal entity of legal monitoring is a governmental body (a local government or an official) which is a developer or adopter of a monitored legal act. Every regulatory entity maps out their monitoring plan independently and there is no requirement to keep monitoring plans similar to each other.

The distributed model of legal monitoring has been implemented in the Kyrgyz Republic and the Republic of Belarus. According to Part 1 of Article 33-1 of Law of the Kyrgyz Republic dated July 20, 2009, No. 241 'On legal acts of the Kyrgyz Republic', 'law-making bodies or officials shall regularly monitor and evaluate the legal acts they adopt, to determine efficiency and effectiveness thereof'. Part 2 clarifies that 'independent experts and members of the public shall be engaged in monitoring and evaluation of legal acts'. However, as per the classification suggested by Tlembayeva and Turlybek [15], independent experts and members of the public are not entities of but only generic parties to legal monitoring. What this also suggests that the Kyrgyz Republic employs the distributed model of legal monitoring is provisions of Clause 10 of the Procedure for Monitoring and Evaluation of Effectiveness of Legal Acts of the Kyrgyz Republic, approved by Enactment of the Kyrgyz Republic dated March 23, 2015, No. 139, which stipulates that executive bodies shall monitor legal acts that govern activities of such bodies, and monitoring shall be carried out in adherence to the plan approved by the head of the executive body at least once a year.

A similar organizational model of legal monitoring is employed in the Republic of Belarus under Part 1 of Article 75 of Law of the Republic of Belarus dated July 17, 2018, No. 130-3 'On legal acts', under which legal monitoring shall be carried out by 'law-making authorities (officials) and other governmental institutions within their respective competence'. These provisions are clarified by provisions of Clauses 3 and 4 of the Procedure for legal monitoring, approved by Enactment of the Council of Ministers of the Republic of Belarus dated January 30, 2019, No. 65. They stipulate that legal monitoring shall be carried by law-making bodies or officials regularly, usually in adherence to the annual legal monitoring plans regarding the legal acts they adopted or published. The governmental bodies carry out legal monitoring concerning legal acts that govern public relations in the industry where such governmental bodies execute the governmental policy, 
carry out regulation and management. Other governmental institutions carry out legal monitoring of legal acts they developed.

Although monitoring activities are carried out at different hierarchical levels, their planning and execution are carried out in a centralized manner under the centralized model of legal monitoring. The Russian Federation is currently employing this very organizational model of legal monitoring.

Under Procedure for Law Implementation Monitoring in the Russian Federation, approved by Decree of the President of the Russian Federation dated May 20, 2011, No. 657, the entities of law implementation monitoring are:

The Government of the Russian Federation, which:

1) Approves the monitoring plan on an annual basis.

2) Submits, on an annual basis, the monitoring results report to the President of the Russian Federation.

3) In the legislative drafting plan, provides for the suggestions on adopting or publishing, changing, or repealing of legal and other regulatory acts of the Russian Federation, submitted as part of the monitoring results report to the President of the Russian Federation.

Ministry of Justice of the Russian Federation, which:

1) Carries out monitoring of law implementation in Russia, to execute the resolutions of the Constitutional Court of the Russian Federation and Decrees of the European Court of Human Rights, which require adoption or publishing, change, or repeal of legal and other regulatory acts of the Russian Federation.

2) Manages monitoring by federal executive bodies and provides procedural guidelines.

3) Develops the annual monitoring plan.

4) Annually prepares and submits the monitoring results report draft to the President of the Russian Federation and makes suggestions for the legislative drafting plan of the Government of the Russian Federation based on the monitoring results reports of federal executive bodies and executive bodies of the constituents of the Russian Federation (which cover these bodies' activity in the previous year) and other materials submitted to the Ministry.

5) After the review by the President of the Russian Federation, publishes the monitoring results report on public resources.

Federal executive bodies.

Executive bodies of the constituents of the Russian Federation.

The Ministry of Justice of the Russian Federation develops the integrated law implementation monitoring plan. The suggestions to that plan are submitted by:

Governmental bodies of the constituents of the Russian Federation, given the suggestions submitted by local governments, public institutions, and mass media.

Federal executive bodies and other federal governmental bodies, given the suggestions submitted by public institutions and mass media.

The Investigative Committee of the Russian Federation.

The Prosecutor General's Office of the Russian Federation.
The Commissioner for Human Rights of the Russian Federation.

Children's Rights Commissioner for the President of the Russian Federation.

The Accounts Chamber of the Russian Federation.

The Central Election Commission of the Russian Federation.

The Central Bank of the Russian Federation.

The Civic Chamber of the Russian Federation.

Governmental corporations, foundations and other organizations established by the Russian Federation under a federal law.

The law implementation monitoring plan for the following year is approved by the Government of the Russian Federation.

The following institutions submit the reports covering the results of monitoring activities they carried out as per the approved plan, to the Ministry of Justice of the Russian Federation:

Federal executive bodies.

Executive bodies of the constituents of the Russian Federation

Other bodies and organizations which are not entities, but participants of law implementation monitoring may advance their suggestions for the draft report to be submitted to the President of the Russian Federation.

A feature that distinguishes the Russian Federation from other EEU member states is that Russia is a federative state, which means law implementation monitoring is carried out at the federal level, at the level of the constituents of the Russian Federation and the municipal level. The analysis of how monitoring procedures are governed by constituent's legislation indicates that different constituents employ different organizational monitoring models. The Republic of Buryatia, Altai Republic, Krasnodar Krai, Primorsky Krai, Kaliningrad Region, Oryol Region and Lipetsk Region employ the distributed law implementation monitoring model. The Republic of Khakassia, Pskov Region, Volgograd Region and some other constituents of the Russian Federation employ the centralized law implementation monitoring model.

Some, including the Republic of Chuvashia, Amur Region, Kaluga Region and Lipetsk Region, employ the two-tier model under which the decision on monitoring legislation is made by the head of a law-making body of that constituent. The decision on monitoring bylaws is made by the principal officer of a constituent of the Russian Federation or the head of the principal executive body of that constituent of the Russian Federation.

Regardless of the organizational model, the entities at the regional level are governmental bodies of the respective constituent or, in some cases, local governments. The entities of legal monitoring studies carried out at the constituent level may be:

Deputies of law-making bodies of the constituents of the Russian Federation or deputy associations.

The Public Chamber of a constituent of the Russian Federation. 
The Commissioner for Human Rights of a constituent of the Russian Federation.

The Commissioner for Children's Rights of a constituent of the Russian Federation.

Local governments of municipal formations in a constituent of the Russian Federation.

Governmental institutions of a constituent of the Russian Federation or structural subdivisions thereof.

Scientific organisations, higher education institutions, other organisations, independent experts and other citizens engaged by the entities of monitoring in executing monitoring activities

At the municipal level, the most widespread model is the centralized version. Under this model, the entity that develops a monitoring plan draft and a law implementation monitoring results report is a local government or its structural subdivision concerned with legal matters. Municipal institutions and other parties engaged by the entities of monitoring in executing monitoring activities are the participants of legal monitoring studies.

In the Republic of Kazakhstan and the Kyrgyz Republic, governmental bodies monitor legal acts 'adopted or developed by them or which fall within their competence'. This is prescribed in Part 2 of Article 50 of Law of the Republic of Kazakhstan dated April 6, 2016, No. 480-V ZRK 'On legal acts'. The provisions of this Part are clarified in provisions of Decree of the President of the Republic of Kazakhstan dated April 27, 2010, No. 976, according to which monitoring of the Decrees of the President of the Republic of Kazakhstan must be regular activities carried out by governmental bodies that developed them, or by structural subdivisions of the Presidential Office which monitors Decrees developed by the Presidential Office. these provisions are clarified in the procedure for legal monitoring approved by Decree of the Government of the Republic of Kazakhstan dated August 29, 2016, No. 486, according to which structural subdivisions of governmental bodies must carry out legal monitoring concerning legal acts adopted or developed by them or which fall within their competence.

While carrying out legal monitoring studies, governmental bodies are entitled to engage public and scientific institutions and citizens. It is not an obligation but a right of every citizen to participate in such studies and they are entitled to use this right in the manner required by law but at their discretion.

Under Clause 7 of the procedure, the Ministry of Justice of the Republic of Kazakhstan and local justice departments of regions, city of Astana and city of Almaty coordinate legal monitoring activities carried out by governmental bodies. Governmental bodies interact in an automated way using the subsystem 'Legislation Monitoring' of the Ministry of Justice's corporate portal. This resource provides a space for discussing, analyzing and generalizing information governmental bodies provide. Here the departments act as coordinators rather than an entity of legal monitoring [15] under Clause 13 of the procedure, according to which the schedule of legal monitoring is approved by the order of a head of a governmental body. The procedure does not prescribe mandatory alignment of the plans of legal monitoring studies carried out by an entity of legal monitoring, with similar plans of other entities of legal monitoring. Thus, the Kazak system can be recognized as two-tier, as it comprises patterns of both the distributed and the centralized models.

The results allow defining legal monitoring carried out in member states as a methodically grounded, integrated, systematic activity aimed at analyzing and evaluating the quality of legislation and its implementation to fulfil the purposes and expected results of legal regulation of public relations. Nevertheless, the existing terminological differences in how this legal technique is described, which reflect deeper differences as to what this legal technique is and in which spheres of public life it is used, reduce the efficiency of legal monitoring.

Another shortcoming of regulatory activities in member states is that the legal acts that govern these activities do not prescribe monitoring how member states perform the international treaties which are part of the Union's treaty framework. Nor do they prescribe monitoring how the resolutions adopted by the Commission are executed.

\subsection{Monitoring Studies Carried out by the Governing Bodies of the EEU}

The analysis of the Union's regulations suggests the following legal monitoring studies carried out in the EEU:

Monitoring and enforcement of the international treaties that are part of the Union's legal framework and resolutions of the Eurasian Economic Commission.

Monitoring and comparative analysis of the legislation of member states in specific economic industries, as to compliance thereof with obligations under the Union law.

Monitoring of evaluation of the regulatory effect of legally-binding resolutions of the Commission.

For every legal monitoring study, the EEU Treaty and supporting resolutions adopted by the Union's governing bodies define the purpose of the study, the objects and entities of monitoring, the regularity of monitoring and the expected results (see Appendix 2). However, despite the value of monitoring studies in terms of improving the efficiency of the $\mathrm{EEU}$, the EEU legal acts prescribe an inadequate procedure for such studies.

In particular, the Regulation on the Eurasian Economic Commission (the EEC Regulation), which is an integral part of the EEU Treaty, defines only the aspects to which structural subdivisions of the Commission are the entities of monitoring. ${ }^{9}$ They do not stipulate any principles the Commission must adhere to when carrying out the studies or its purposes, boundaries or intended results thereof.

Information as to monitoring activities is often siloed. For instance, the Commission's internet portal has a special section 'Monitoring of Treaty Execution Performance' for the Department of Energy. Analysis of this section shows that it only provides a list of events of signing and ratifying

9 See Subclause 4 of Clause 24, Subclause 4 of Clause 43 and Subclause 2 of Clause 55 of the Regulation on the Eurasian Economic Commission. 
energy-related treaties and information regarding planned research in this field. The timeframe of this monitoring is limited to 2014-2015 and no results as to execution or performance are provided. ${ }^{10}$

As the World Health Organization deemed the COVID-19 outbreak a pandemic in March 2020, Order of the Chairman of the Board of the EEC dated March 19, 2020, prescribed establishment of a Coordinating Council to monitor prevention of the spread of the infection and response measures. The purpose of establishing the Council was:

"assisting the governments of the Union member states in combating the coronavirus infection and developing the coordinated measures and recommendations as to securing public health, preventing the spread of the coronavirus infection in the member states, given the necessity for maintaining the macroeconomic stability, epidemiological welfare, free commodity trade, labor mobility in the member states". 11

The Coordination Council was tasked to monitor implementation of the measures in member states aimed, publish related information on the EEU's official website, define the information exchange mechanisms, and to contribute to operation and implementation of the resolutions of the Council of Heads of Authorized Agencies supervising the sanitary and epidemiological situation.

This body regularly publishes reports entitled 'Monitoring of measures taken by member states, aimed at controlling the adverse consequences of the spread of the coronavirus infection (COVID-19)' on its website. However, those reports are more informational than analytical and do not clarify what result the monitoring activities are expected to secure and under what principles measures are included in the report. For instance, in the report dated May 29, 2020, the measures taken by the President of the Russian Federation and the Government of the Russian Federation are discussed but there is no analysis. Legal acts of the EEU, including those regulating the activities of the Coordination Council, provide no clarification.

In the Russian Federation at the federal level, from the beginning of the pandemic to July 1 , over 500 regulatory acts from federal law to departmental regulations were adopted and almost 600 informational documents published, all aimed at reducing the spread of the coronavirus infection and mitigating its effects on Russia's economic and social growth. Similar acts have been adopted by the EEU. For instance, Decree No. 11 'On implementing the measures intended to prevent the spread of the COVID-19 infection', which regarded the joint and coordinated activities of member states as to a wide range of aspects of implementing such measures, was adopted at the extraordinary meeting of the Board of the Eurasian Economic Commission that was held on March 25,

10 See official website of the Eurasian Economic Commission, http:///www.eurasiancommission.org/ru/act/energetikaiinfr/energ/monitoring/Page s/default.aspx/.

11 See official website of the Eurasian Economic Commission, http://www.eurasiancommission.org/ru/nae/news/Pages/19-03-2020-4.aspx Accessed on August 7, 2020.
2020. As part of what was concluded, the parties agreed to:

Exchange information and hold ad-hoc consultations on the anti-COVID-19 measures taken and national regulations adopted.

Continuously coordinate activities of national healthcare and epidemiological authorities.

Develop the procedures for lending mutual support, including humanitarian aid and commercial supplies to each other in case of a commodity deficit.

The parties also defined a special manner of entry into force of resolutions governing the response to the spread of the coronavirus infection (customs and tariff, non-tariff and customs regulation; transport, sanitary, veterinary and sanitary, quarantine phytosanitary control; technical regulation and labor migration). On April 16, Decree of the Eurasian Intergovernmental Council's Meeting dated April 10, 2020, No. 6 'On the EEU's measures intended to ensure economic stability amidst the spread of the COVID-19 pandemic' was published, defining the following:

Ad-hoc temporary crisis response and stabilization measures - for instance, establishment of a green channel to allow importing critical goods or imposing unified temporary restrictions as to exporting critical goods.

Measures on restoring the economy and securing future economic growth (e.g. contribution to trade digitalization).

The Eurasian Economic Commission adopted a set of resolutions. $^{12}$

Some of the acts are temporary. For instance, the ban on the export of certain food products from member states, imposed by Decree of the Board of the EEC dated March 31, 2020 , No.

12 Those include: Resolution of the Board of the EEC dated March 16, 2020 No. 21 'On amendments to resolutions of the Customs Union Commission and approval of the list of the goods imported into the customs area of the Eurasian Economic Union to secure implementation by the member states of the Eurasian Economic Union of measures aimed at preventing the spread of the COVID-19 infection'; Resolution of the Board of the EEC dated March 24, 2020 No. 41 'On amendments to Resolution of the Board of the Eurasian Economic Commission dated April 21, 2015 No. 30 'On measures of non-tariff regulation'; Decree of the Board of the Eurasian Economic Commission dated March 25, 2020 No. 11 'On implementing the measures intended to prevent the spread of the COVID-19 infection'; Resolution of the Board of the Eurasian Economic Commission dated March 31, 2020 No. 42 'On amendments to the list of goods that are considered critical to the domestic market of the Eurasian Economic Union and which may - in extraordinary cases - subject to temporary or quantitative export restrictions'; Resolution of the Board of the Eurasian Economic Commission dated March 31, 2020 No. 43 'On amendments to Resolution of the Board of the Eurasian Economic Commission dated April 21, 2015 No. 30 'On measures of non-tariff regulation'; Resolution of the Council of the Eurasian Economic Commission dated April 3, 2020 No. 33 'On amendments to specific resolutions of the Customs Union Commission; and on approval of the list of critical imported goods'; Resolution of the Council of the Eurasian Economic Commission dated April 3, 2020 No. 34 'On amendments to the list of goods imported into the customs area of the Eurasian Economic Union to enable the member states of the Eurasian Economic Union to implement measures aimed at preventing the spread of the COVID-19 infection'; Resolution of the Council of the Eurasian Economic Union dated April 3, 2020 No. 36 'On amendments to the Rules for determining origin of goods from emerging and underdeveloped nations and on specifics of submitting a certificate of origin, during the COVID-19 pandemic'; Decree of the Eurasian Intergovernmental Council dated April 10, 2020 No. 6 'On the Eurasian Economic Union's measures intended to ensure economic stability amidst the spread of the COVID-19 pandemic'. 
43, expired on July $1,2020 .{ }^{13}$

Neither the anti-COVID-19 legal acts adopted by the EEU governing bodies and governmental bodies of member states, nor the way they were implemented during legal monitoring carried out by the EEC and other entities, were studied in full.

Union law does not comprehensively govern how monitoring activities are organized. There are two models under which the monitoring is conducted. In the first, monitoring is carried out by the EEC and requests signed by an EEC Board member are submitted by the Commission to the public authorities of the member states. The EEC's right to submit such requests does not imply that the governmental bodies of member states are obliged to meet such requests. Neither the EEU Treaty nor any body of Union law, nor domestic legislation of EEU member states prescribes such an obligation. Thus, governmental bodies of member states often ignore these requests, which reduce the effectiveness of the EEC's monitoring activities.

Under the second model, monitoring of EEU legal acts is carried out by the public authorities of member states, which are anyway key participants in monitoring carried out under the authority of the EEC. Cases of member states violating international treaties and other acts of law can be handled quickly using monitoring. It is reasonable that monitoring is carried out by authorities responsible for compliance with and adherence to the respective legal acts of the Union and this generates a need for assigning a monitoring coordinator.

Even this model has downsides. For one, there is duplication of monitoring functions. The existing national methodologies are not intended for monitoring resolutions of supranational authorities. Therefore, if member states employ monitoring methodologies that differ from each other and the EEC's developments in this field, there is a risk of differences in monitoring and a lack of unified criteria and performance indicators. All this may result in difficulties collating monitoring results in different EEU member states, while the EEC may have a different position as to the monitoring objects from the positions of member states' governmental bodies.

Both models share a common disadvantage in the lack of engagement of scientific and business people in monitoring activities. Entrepreneurs are especially interested in monitoring and can provide valuable and unbiased insights as to law implementation. It is reasonable to engage them in monitoring activities and recognize their rights in the legally-binding regulations that regulate the procedures for monitoring studies.

Defining how the monitoring entities are supposed to interact raises a question of technological aspects and thus the development of software to enable monitoring data exchange. The problem is choosing how to use such software, which must imply unified formats and techniques for exchanging monitoring data.

The first option is creating bespoke software for monitoring

13 See official website of the Eurasian Economic Commission, http://eec.eaeunion.org/ru/covid-19/Pages/measures.aspx Accessed on August 8, 2020 purposes. However, this has distinct shortcomings that include significant time, financial and other efforts; and the necessity for training the monitoring entities' officers and other responsible persons by the EEC and member states, which also entails a wide scope of costs and expenses. Yet another downside is inflation of the EEU data systems and dedicated software.

Another option is using the EEU's existing data systems in monitoring activities. An example is the Russian Customs Service Unified Automated Data System. Alternatively, it is possible to establish interaction between the monitoring entities through modernizing and upgrading the EEC's existing website by creating a new service.

It is assumed that the EEC's structural subdivision responsible for coordinating monitoring activities in the Commission must be the Legal Department. The Legal Department will generalize the information as to the performance by member states of the international treaties and resolutions; and prepare the consolidated monitoring information to submit to the Commission Board. Also, the Legal Department will prepare the consolidated report on all monitoring activities carried out within the year and submit it to the Chairman of the Board of the EEC in the prescribed manner. This forms a bedrock for a holistic monitoring mechanism to operate within the EEU which will incorporate the coordinated characteristics of integrational legal acts, with methods and criteria for analyzing and assessing; methods for implementing integrational acts; procedures for the coordinated activity of the Union's bodies and member states' bodies; and the procedure for implementing the results and recommendations delivered during monitoring activities.

The advantage of this legal monitoring methodology is versatility, which means it can be applied to all the industries and laws of a subject nation. However, the analysis revealed a gap between the monitoring methods employed at the national and the international levels, which is inappropriate given the development and implementation of acts of an international association like the EEU. Discrepancies were found in the monitoring performance indicators, objects and entities and the criteria for evaluating the implementation of national and international acts that concern the same or homogeneous scopes of regulation. All this makes comparing the monitoring results in different countries very hampered.

In this context, it is reasonable that the Eurasian Economic Commission adopts:

1) A legally-binding act that will govern and stipulate how the EEC must carry out different kinds of legal monitoring studies prescribed by the EEU Treaty.

2) Methodological recommendations of legal monitoring to ensure consistency of monitoring practices among member states.

\section{Conclusion}

The analysis suggests that legal monitoring is being used 
actively in the Eurasian economic space both at the supranational level and at the level of the member states. In particular, the following monitoring studies are carried out in the EEU as prescribed by the EEU Treaty:

Monitoring and enforcement of the international treaties and resolutions of the Eurasian Economic Commission, the Board of the Eurasian Economic Commission, the Eurasian Intergovernmental Council and the Supreme Eurasian Economic Council, which are part of the Union law.

Monitoring and comparative analysis of the legislation of member states in specific economic industries, as to compliance thereof with obligations under the Union law.

Monitoring of evaluation of the regulatory effect of the EEC's legally-binding resolutions.

With that,

The Union does not define the term 'legal monitoring'.

Union law ill-defines the procedure for legal monitoring studies. In particular, the Regulation on the Eurasian Economic Commission, which is an integral part of the EEU Treaty, only defines which structural subdivisions of the Commission are monitoring entities and not the principles the Commission must adhere to when carrying out legal monitoring.

Union law does not comprehensively govern the issues as to how monitoring activities are organized.

The study has led the authors to propose two possible ways to organize monitoring of the EEU legal acts:

1) Monitoring is carried out by the Commission. A drawback of this model is the lack of a holistic legal and organizational framework of monitoring activities.

2) Monitoring is carried out by the Commission and authorities of the member states. A disadvantage of this option is duplicated monitoring-related functions. The existing national procedures for legal monitoring studies are also not intended for monitoring resolutions of the supranational authorities and international legal acts.

The analysis of legal regulation of monitoring studies in the EEU studies enabled to identify several organizational models of legal monitoring, which include:

1. Distributed legal monitoring model. It is characterized by the following:
Multiplicity and equivalence of legal monitoring entities.

Under this model, the principal entity of legal monitoring is the governmental body (a local government or an official) which is a developer or adopter of a monitored legal act.

Every regulatory entity maps out its monitoring plan independently; there is no requirement to keep monitoring plans similar.

This organizational model is implemented in the Republic of Belarus, Kyrgyz Republic and some constituents of the Russian Federation

2. Centralized legal monitoring model. Its attributes are a hierarchical legal monitoring system where relations between monitoring entities are based on subordination and which implies consistency between monitoring plans of different monitoring entities and the general monitoring plan adopted by the general-power authority. This organizational model is used in the Russian Federation, both at the federal and the municipal levels.

3. Combined monitoring model. Its features include:

A multiplicity of equivalent monitoring entities interactions between which are based on coordination

Every monitoring entity develops a monitoring plan independently.

The study suggests that different approaches to defining legal monitoring and where it is implemented are used at the supranational level and the level of member states. There are several discrepancies between criteria employed to evaluate how national and international legal acts are implemented. Different monitoring indicators are used; monitoring objects and entities also differ. All this hampers comparative analysis of monitoring results in different countries. There is a difference between the monitoring techniques employed at the national and international levels, which is inappropriate in the circumstances.

What might remedy this is the EEC developing methodological recommendations for monitoring procedures to integrate member states and harmonize frameworks governing monitoring processes. Only such a systemic approach can make legal monitoring studies a supranational legal framework able to enhance the efficiency of integrational processes within the EEC.

\section{Appendix}

Table 1. Law Implementation (Regulatory) Monitoring in member states [7].

\begin{tabular}{|c|c|c|c|c|}
\hline Characteristics & Republic of Belarus & Republic of Kazakhstan & Kyrgyz Republic & Russian Federation \\
\hline & Legal monitoring & Legal monitoring & $\begin{array}{l}\text { Monitoring and evaluation of } \\
\text { legal acts }\end{array}$ & Law implementation monitoring \\
\hline Purpose & $\begin{array}{l}\text { Systematic analysis and } \\
\text { evaluation of the quality of } \\
\text { legislation and law } \\
\text { implementation; efficiency of } \\
\text { legal regulation of public } \\
\text { relations }\end{array}$ & $\begin{array}{l}\text { Evaluating and forecasting } \\
\text { legislation efficiency through } \\
\text { identifying elements of the law that } \\
\text { conflict with legislation of the } \\
\text { Republic of Kazakhstan, obsolete, } \\
\text { corrupt and inefficiently } \\
\text { implemented; developing proposals } \\
\text { as to improve national legislation }\end{array}$ & $\begin{array}{l}\text { Identifying obsolete and corrupt } \\
\text { legal acts which conflict with the } \\
\text { law of the Kyrgyz Republic, } \\
\text { evaluating law implementation } \\
\text { efficiency; } \\
\text { Assessing the sufficiency of legal } \\
\text { regulation and identifying } \\
\text { declarative standards; } \\
\text { Eliminating conflicts between } \\
\text { equal-force legal acts, internal } \\
\text { contradictions and gaps in legal }\end{array}$ & $\begin{array}{l}\text { Enhancing the Russian legal } \\
\text { framework, including identifying } \\
\text { conflicts in existing legislation; } \\
\text { evaluating the efficiency of } \\
\text { existing elements of law; } \\
\text { arranging for adoption } \\
\text { (publishing), change, or repeal of } \\
\text { legal acts; evaluating the } \\
\text { adequacy of law implementation } \\
\text { practices to the intended result of } \\
\text { legal regulation }\end{array}$ \\
\hline
\end{tabular}




\begin{tabular}{|c|c|c|c|c|}
\hline Characteristics & Republic of Belarus & Republic of Kazakhstan & Kyrgyz Republic & Russian Federation \\
\hline $\begin{array}{l}\text { Objects of } \\
\text { monitoring }\end{array}$ & $\begin{array}{l}\text { Certain provisions of an adopted } \\
\text { (published) and effective legal } \\
\text { act, except for technical legal } \\
\text { acts concerning technical } \\
\text { standardization, decrees on } \\
\text { adoption thereof or amendments } \\
\text { to technical legal acts } \\
\text { concerning technical } \\
\text { standardization, decrees on } \\
\text { construing, suspension, or } \\
\text { repeal of such legal acts } \\
\end{array}$ & $\begin{array}{l}\text { Constitutional laws, codes, } \\
\text { consolidated laws, laws; } \\
\text { Presidential regulatory decrees; } \\
\text { Governmental decrees; } \\
\text { Decrees of the Central Election } \\
\text { Commission; decrees of the } \\
\text { Accounts Committee for Control } \\
\text { over Execution of the Republican } \\
\text { Budget; decrees of the National } \\
\text { Bank; decrees of other central } \\
\text { governmental bodies; orders of } \\
\text { ministers and other executives of } \\
\text { central governmental bodies; orders } \\
\text { of executives of departments of } \\
\text { central governmental bodies; } \\
\text { Resolutions of local representative } \\
\text { bodies; resolutions of local } \\
\text { administrations; resolutions of } \\
\text { administration executives; } \\
\text { resolutions of revision commissions }\end{array}$ & $\begin{array}{l}\text { regulation; } \\
\text { Securing consistency between } \\
\text { legal acts and newly-adopted legal } \\
\text { acts of a higher legal force; } \\
\text { Preventing the prosecutor's } \\
\text { response to legal acts and } \\
\text { recognition of legal acts } \\
\text { unconstitutional or invalid } \\
\text { Legal acts; } \\
\text { Legal acts governing a specific } \\
\text { field of public relations }\end{array}$ & $\begin{array}{l}\text { Constitution of the Russian } \\
\text { Federation; } \\
\text { Federal constitutional laws; } \\
\text { Federal laws; } \\
\text { Laws of the Russian Federation; } \\
\text { primary legislation of the Russian } \\
\text { Federation; decrees of the } \\
\text { Supreme Council of the Russian } \\
\text { Federation; decrees of the } \\
\text { Congress of People's Deputies of } \\
\text { Russia; decrees and resolutions } \\
\text { of the Presidium of the Supreme } \\
\text { Soviet of the Russian Federation; } \\
\text { Decrees of the President of the } \\
\text { Russian Federation; } \\
\text { Decrees of the Government of the } \\
\text { Russian Federation; } \\
\text { Legal acts of the federal } \\
\text { executive bodies; legal acts of } \\
\text { other governmental bodies and } \\
\text { organisations publishing } \\
\text { respective legal acts }\end{array}$ \\
\hline $\begin{array}{l}\text { Types of } \\
\text { monitoring }\end{array}$ & $\begin{array}{l}\text { Legal monitoring is regularly } \\
\text { carried out by law-making } \\
\text { bodies (officials), other } \\
\text { authorised governmental bodies } \\
\text { (organisations), usually as per } \\
\text { the annually approved } \\
\text { monitoring plans (independent } \\
\text { or part of the annual operation } \\
\text { plans); } \\
\text { A monitoring organiser may } \\
\text { also carry out monitoring } \\
\text { activities to identify and tackle } \\
\text { problems concerning legal } \\
\text { regulation of public relations } \\
\text { and law implementation }\end{array}$ & $\begin{array}{l}\text { Monitoring is carried out in } \\
\text { adherence to the monitoring plan for } \\
\text { the following year; } \\
\text { Side-line legal monitoring is allowed }\end{array}$ & $\begin{array}{l}\text { Branch monitoring carried out } \\
\text { to obtain information as to the } \\
\text { status and implementation of } \\
\text { legal acts governing a specific } \\
\text { law branch; } \\
\text { Single-point monitoring carried } \\
\text { out to obtain information as to } \\
\text { the status and implementation of } \\
\text { a specific legal act }\end{array}$ & $\begin{array}{l}\text { Regular in-process monitoring of } \\
\text { a specific law branch or group of } \\
\text { legal acts; } \\
\text { Ad-hoc monitoring is carried out } \\
\text { during the first year of the legal } \\
\text { act validity or implementation of } \\
\text { resolutions of the Constitutional } \\
\text { f Court and the European Court of } \\
\text { Human Rights }\end{array}$ \\
\hline $\begin{array}{l}\text { Entities of } \\
\text { monitoring }\end{array}$ & $\begin{array}{l}\text { Law-making bodies (or } \\
\text { officials) carry out monitoring } \\
\text { of the legal acts they adopted; } \\
\text { Governmental bodies carry out } \\
\text { legal monitoring of legal acts } \\
\text { regulating public relations in the } \\
\text { industry in which such bodies } \\
\text { implement a governmental } \\
\text { policy, exercise regulation and } \\
\text { management; other } \\
\text { governmental institutions carry } \\
\text { out monitoring of the legal acts } \\
\text { they developed }\end{array}$ & $\begin{array}{l}\text { Governmental bodies carry out } \\
\text { monitoring of legal acts they adopted } \\
\text { or developed or which are within } \\
\text { their competence }\end{array}$ & Executive bodies & $\begin{array}{l}\text { The Government of the Russian } \\
\text { Federation, federal executive } \\
\text { bodies, governmental bodies of } \\
\text { the constituents of the Russian } \\
\text { Federation and local } \\
\text { governments }\end{array}$ \\
\hline
\end{tabular}

Table 2. Legal Monitoring Studies in the EEU [8].

\begin{tabular}{|c|c|c|c|c|c|}
\hline $\begin{array}{l}\text { Legal technique } \\
\text { (Legal procedures }\end{array}$ & $\begin{array}{l}\text { Purpose of the } \\
\text { study }\end{array}$ & $\begin{array}{l}\text { Objects of } \\
\text { monitoring }\end{array}$ & Entities of monitoring & Regularity & Result \\
\hline $\begin{array}{l}\text { Monitoring and } \\
\text { enforcement of the } \\
\text { international treaties } \\
\text { and resolutions of the }\end{array}$ & $\begin{array}{l}\text { Check if the } \\
\text { obliged entities } \\
\text { comply with the } \\
\text { elements of law }\end{array}$ & $\begin{array}{l}\text { International treaties } \\
\text { which are part of the } \\
\text { Union law, } \\
\text { Resolutions of the }\end{array}$ & $\begin{array}{l}\text { Departments of the EEC (carry out } \\
\text { monitoring and submit monitoring } \\
\text { results to the Board of the EEC); } \\
\text { Members of the Board of the EEC }\end{array}$ & One-time & $\begin{array}{l}\text { In case of identifying } \\
\text { non-compliance of the obliged } \\
\text { entities with the elements of law or } \\
\text { regulations, the jurisdictional body }\end{array}$ \\
\hline
\end{tabular}




\begin{tabular}{|c|c|c|c|c|c|}
\hline $\begin{array}{l}\text { Legal technique } \\
\text { (Legal procedures }\end{array}$ & $\begin{array}{l}\text { Purpose of the } \\
\text { study }\end{array}$ & $\begin{array}{l}\text { Objects of } \\
\text { monitoring }\end{array}$ & Entities of monitoring & Regularity & Result \\
\hline $\begin{array}{l}\text { EEC, constituting the } \\
\text { Union law }\end{array}$ & and regulations & EEC & $\begin{array}{l}\text { (carry out monitoring regarding the } \\
\text { matters within their competence); } \\
\text { The Board of the EEC } \\
\text { (carries out monitoring and } \\
\text { enforcement of the international } \\
\text { treaties and resolutions of the EEC, } \\
\text { informs the member states of their } \\
\text { obligation to perform the } \\
\text { aforementioned regulations); } \\
\text { The Council of the EEC } \\
\text { (reviews monitoring results) }\end{array}$ & & $\begin{array}{l}\text { adopts an individual resolution on } \\
\text { urging the non-compliant entity to } \\
\text { adhere to the aforementioned } \\
\text { regulations }\end{array}$ \\
\hline $\begin{array}{l}\text { Monitoring and } \\
\text { comparative analysis } \\
\text { of the legislation of } \\
\text { member states in } \\
\text { various fields of the } \\
\text { economy as to } \\
\text { adequacy to the } \\
\text { obligations under the } \\
\text { Union law }\end{array}$ & $\begin{array}{l}\text { Enforcement of } \\
\text { obligations of } \\
\text { member states } \\
\text { concerning legal } \\
\text { regulation of the } \\
\text { respective fields } \\
\text { of economy }\end{array}$ & $\begin{array}{l}\text { Legal acts and drafts } \\
\text { of legal acts of } \\
\text { member states that } \\
\text { govern the respective } \\
\text { fields of economy }\end{array}$ & $\begin{array}{l}\text { Structural subdivisions of the EEC } \\
\text { whose competence encompasses } \\
\text { monitoring-related functions; } \\
\text { Executive bodies of member states, } \\
\text { acting as requested by the EEC }\end{array}$ & $\begin{array}{l}\text { Regularly; } \\
\text { One-time } \\
\text { (upon request } \\
\text { of a member } \\
\text { state) }\end{array}$ & $\begin{array}{l}\text { Resolution on the adequacy of legal } \\
\text { acts or drafts thereof, governing the } \\
\text { respective fields of economy, to the } \\
\text { EEU Treaty or international legal acts } \\
\text { that constitute the Union law and } \\
\text { legal acts of the supranational law; } \\
\text { Informing member states of their } \\
\text { obligation to implement provisions of } \\
\text { the EEU Treaty and other } \\
\text { international legal acts and legal acts } \\
\text { of the supranational law; } \\
\text { Assisting member states in } \\
\text { organising consultations as to } \\
\text { harmonisation and unification of } \\
\text { legislation governing the respective } \\
\text { fields of economy }\end{array}$ \\
\hline $\begin{array}{l}\text { Monitoring of } \\
\text { evaluation of the } \\
\text { regulatory effect of } \\
\text { legally-binding } \\
\text { resolutions of the } \\
\text { Eurasian Economic } \\
\text { Commission }\end{array}$ & $\begin{array}{l}\text { Enhancing the } \\
\text { EEC's } \\
\text { law-making } \\
\text { activities }\end{array}$ & $\begin{array}{l}\text { Legally-binding } \\
\text { resolutions of the } \\
\text { EEC; } \\
\text { Opinions on the } \\
\text { regulatory effect of the } \\
\text { EEC's legally-binding } \\
\text { resolutions }\end{array}$ & $\begin{array}{l}\text { Structural subdivisions of the EEC } \\
\text { whose competence encompasses } \\
\text { monitoring-related functions }\end{array}$ & Annually & $\begin{array}{l}\text { Proposals as to enhancing the } \\
\text { procedure for evaluating the } \\
\text { regulatory effect of the EEC's } \\
\text { legally-binding resolutions; } \\
\text { Proposals to make amendments to the } \\
\text { Commission's resolutions which } \\
\text { have or may harm the entrepreneurial } \\
\text { environment }\end{array}$ \\
\hline
\end{tabular}

\section{Acknowledgements}

The article was prepared within the framework of the RFBR grant 18-29-15009 — Scientific activities of international organizations and their contribution to the development of legal regulation of regional integration in the Eurasian space.

\section{References}

[1] Gagik G. Harutyunyan. Constitutional monitoring. Erevan. Nijar. 2016. 351 p.

[2] Fadeeva A. S. Analytical function of legal monitoring. Author's abstract of the thesis for the degree of candidate of jurisprudence, Moscow. p. 14.

[3] Gorokhov D. B. \& Radchenko V. I. \& Chernogor N. N. et al. 2010 Legal monitoring: actual problems of theory and practice: monograph. International Law Institute. Moscow.

[4] Ivanova L. A. 2011. Determining the effectiveness of regulations in the process of legal monitoring: Author's abstract of the thesis for the degree of candidate of jurisprudence, Moscow. p. 14.

[5] Kapustin A. Ya. 2015. The Law of Eurasian Economic Union: International Legal Discourse. Journal of Russian Law. Issue 11, Moscow. pp. 59-69.
[6] Kashirkina A. A., Morozov A. N. Legal aspects of integration in the post-Soviet space within the framework of the EurAsEC: problems and prospects // Journal of Russian Law. Issue 2, Moscow. p. 98.

[7] Lukyanova V. Yu. \& Pavlushkin A. V. 2019. New Legal Technologies in the States Participating in the Eurasian Economic Union. Foreign Law and Comparative Legal Science Journal. Issue 5. Moscow. pp. 50-51.

[8] Lukyanova V. Yu. \& Pavlushkin A. V. 2019. LEGAL MONITORING STUDIES IN THE EURASIAN ECONOMIC UNION // Journal of Russian Law. Issue 11. Moscow.

[9] Neshatayeva T. N. 2015. Uniform law enforcement-the goal of The Court of the Eurasian economic Union. International justice. 2015. no. 2. Pp. 115-125.

[10] Neshatayeva T. N. eds. 2015. Eurasian integration: the role of the Court p. 27. Moscow.

[11] Polyashchuk N. A. 2018a. Legal monitoring in digital reality: experience of the Republic of Belarus. Foreign Law and Comparative Legal Science Journal. Issue 6, Moscow. pp. 79-84.

[12] Polyashchuk N. A. 2018b. Institutionalization of legal monitoring in the Republic of Belarus. Electronic library of legal science papers on the National Legislation and Legal Study Center of the Republic of Belarus. Digital resource: https://zakonrb.com/npa/polyashchuk-na-institualisaciya-prav ovogo-monitoringa Accessed on August 6, 2020. 
[13] Report of the Court of the Eurasian Economic Community. Special 2012-2014 Issue.

[14] Tikhomirov Yu. A. 2006. Organization and conduct of legal monitoring. Law and Economics. Issue 10, Moscow. p. 13.

[15] Tlembayeva Zh. U. \& Turlybek D. M. 2018. Legal Monitoring as a Tool for Modernization of National Legal System of the Republic of Kazakhstan. Foreign Legislation and Comparative Legal Science Journal. Issue 4 (71), Moscow. p. 5.
[16] Tolmachyova N. N. 2006. On some problems of ensuring the effectiveness of legislative regulation of economic transformations. Journal of Russian Law. Issue 10, Moscow. pp. 83-84.

[17] The Treaty of the Eurasian Economic Union dated May 29, 2014, http://www.eurasiancommission.org/, June 5, 2014. 